FULLER, J. L., \& THOMPSON, W. R. Behavior genetics. New York: Wiley, 1960.

KINDER, E. F. A study of the nest-building activity of the albino rat. Journal of Experimental Zoology, 1927, 47, 117-161.

KOLLER, G. Hormonale und psychische Steuerung beim Nestbau weisser Mause. Zoologischen Anzeiger Supplementband, 1956, 19, 123-132.

LEE, $C$. T. The nest-building behavior of inbred mice. Developmental and genetic studies.
Unpublished doctoral dissertation, Bowling Green State University, 1969.

PARSON, P. A. The genetic analysis of behavior. London: Methuen, 1967.

STRICKER, E. M., EVERETT, J. C., \& PORTER, R. E. A. The regulation of body temperature by rats and mice in the heat: Effects of desalivation and the presence of a water bath. Communications in Behavioral Biology, 1968, Part A, 2, 113-119.

\section{Facilitation of learning by injection of brain extracts*}

\section{GEORGES CHAPOUTHIER $†$ and ARIELLE UNGERER \\ Laboratoire de Psychophysiologie \\ 7, rue de l'Universite, Strasbourg, France}

The rate at which mice acquire a single conditioned avoidance response is increased by the injection of suitably concentrated brain extract from conditioned animals. This effect cannot be attributed to an increase in general activity of the treated animals.

The possibility of inducing behavioral changes by administration of brain extracts was first reported in 1965 (Reinis; Fjerdingstad, Nissen, \& R $\phi i g a a r d-P e t e r s e n ;$ Ungar \& Oceguera-Navarro; Babich, Jacobson, Bubash, \& Jacobson) and the reports have been confirmed in the last few years in at least 15 other laboratories (Ungar, in press). The negative results obtained by some workers (Byrne et al, 1968) can be explained by inadequate training of donors, insufficient doses of extract administered, or confusion over the nature of the active material, which resulted in the use of inactive preparations (Ungar in press).

\section{METHOD}

The experiments reported in this paper were carried out in Swiss mice (male, 2 to 3 months old). The donors were trained to acquire a simple conditioned-avoidance response in a shuttlebox $(24 \times 12 \times 12 \mathrm{~cm})$ whose two compartments were divided by an opaque partition provided with an opening. Before the first trial, each animal was allowed to explore the apparatus freely for $10 \mathrm{~min}$. The trial consisted in the presentation of the conditioned stimulus (sound coupled with light) for $5 \mathrm{sec}$ followed by an electric shock of 30 to $40 \mathrm{~V}$ through the grid that formed the

*We thank Professor L. Hirth and Miss G. Lebeurier for use of their equipment, Miss $O$. Maurer for technical assistance, and Dr. P. Guiton for help in the preparation and translation of the manuscript.

†Present address: Department oi Anesthesiology, Baylor College of Medicine, Texas Medical Center, Houston, Tex. 77025. floor of the box. Correct response was recorded when the mouse ran into the other compartment on the conditioned stimulus and thereby avoided shock. Each animal was given 20 trials daily until the criterion of $90 \%$ correct responses on five consecutive sessions was reached

The donors were killed $24 \mathrm{~h}$ after the last training session. Their brains were rapidly removed and kept at $-40^{\circ} \mathrm{C}$. Control brains were taken from untrained donors and treated identically with those collected from trained animals. Each group consisted of 48 animals.

Pooled brains from each group were homogenized in saline. The homogenates were kept overnight at $2^{\circ} \mathrm{C}$ and centrifuged for $2 \frac{1}{2} \mathrm{~h}$ at $24,000 \times \mathrm{g}$. The supernatant was injected intraperitoneally into recipients: one group of 12 mice received the equivalent of four brains from trained donors (CR) and a second group of 12 the same amount from naive donors (NR).

Twenty-four hours after the injection, the recipients were trained identically with the donors. During the 10 -min exploratory period, the number of times the animals moved from one compartment to the other

Table 1

Rate of Conditioning and Exploratory Activity in Mice Injected with Brain Extracts from Trained (CR) and Naive Donors (NR)

\begin{tabular}{lccccc}
\hline & $\begin{array}{c}\text { Mean } \\
\text { Number of } \\
\text { Errors to } \\
\text { Group }\end{array}$ & $\begin{array}{c}\text { Criterion } \\
\text { Index } \\
\text { of }\end{array}$ & $\begin{array}{c}\text { ISD } \\
\text { Activity }\end{array}$ & \pm SD & N \\
\hline CR & 71.1 & 25.8 & 33.6 & 5.7 & 12 \\
NR & 122.4 & 47.0 & 34.7 & 7.4 & 12 \\
P & $<0.01$ & & $>0.05$ & & \\
\hline
\end{tabular}

was recorded, and this value was used as an index of activity. Performance of the recipients was expressed in terms of the number of errors made before the $90 \%$ criterion at two consecutive sessions was attained.

Table 1 shows that Group CR made fewer errors than Group $\mathrm{CN}$. An analysis of variance showed that the difference was significant to the level of $\mathrm{p}<0.01$. There was no significant difference in exploratory activity between the two groups.

The results of these and of our previous experiments (Chapouthier, Pallaud, \& Ungerer, 1969) suggest that the brain of trained animals contains some material, absent from the brain of untrained animals, which accelerates the rate of learning in the recipients. They confirm the results previously obtained with conditioned avoidance by Ungar (1966) who, however, used rats as donors. Our results indicate that the increased learning ability of the experimental group is not due to higher spontaneous activity, but they do not allow us to decide whether it is specific for the task learned by the donors or reflects an overall facilitation of learning by some material present in the brain of trained animals.

\section{REFERENCES}

BABICH, F. R., JACOBSON, A. L., BUBASH, S. \& JACOBSON, A. Transfer of a response to naive rats by injection of ribonucleic acid extracted from trained rats. Science, 1965, 149, 656-657.

BYRNE, W. L., SAMUEL, D., BENNETT, E. L., ROSENZWEIG, M. R., WASSERMAN, E., WAGNER, A. R., GARDNER, R., GALAMBOS, R., BERGER, B. D., MARGULES, D. L., FENICHEL, R. L. STEIN, L., CORSON, J. A., ENESCO, H. E., CHOROVER, S. L., HOLT, C. E., III, SCHILLER, P. H., CHIAPETTA, L., JARVIK, M. E., LEAF, R. C., DUTCHER, J. D., HOROVITZ, Z. P., \& CARLSON, P. L. Memory transfer. Science, 1966, 153, 658-659.

CHAPOUTHIER, G., PALlaUd, B., \& UNGERER, A. Note préliminaire concernant l'effect sur l'apprentissage des broyats de cerveau conditionné. Revue du Comportement Animal, 1969, 3, 55-63.

FJERDINGSTAD, E. J., NISSEN, Th., \& R $\emptyset$ IGAARD-PETERSEN, H. H. Effect of ribonucleic acid (RNA) extracted from the brain of trained animals on learning in rats. Scandinavian Journal of Psychology, 1965, 6, $1-6$.

REINIS, S. The formation of conditioned reflexes in rats after the parenteral administration of brain homogenates. Activitas Nervosa Superior, 1965, 7, 167-268.

UNGAR, G. Chemical transfer of acquired information. Proceedings of C.I.N.P., Washington, D.C., March 1966, Excerpta Medica, Amsterdam, 1967.

UNGAR, G. Chemical transfer of acquired information. In A. Schwartz (Ed.), Methods in pharmacology. New York: Appleton-Century-Crofts, in press.

UNGAR, G., \& OCEGUERA-NAVARRO, C. Transfer of habituation by material extracted from brain. Nature, 1965, 207, 301-302. 